
East Central Europe.” AHEA: E-journal of the American Hungarian Educators Association, Volume 5 (2012): http://ahea.net/e-journal/volume-5-2012

\title{
Will Hungarian Private Collectors Turn International? Private Engagement in Contemporary Art in East Central Europe
}

\author{
Gábor Ébli, Moholy-Nagy University, Budapest
}

\begin{abstract}
The recent spectacular surge in private collecting in Hungary - which began around the fall of Communism and abated only with the current financial crisis - can be seen as part of the steady expansion of private involvement in the art scene, with some of these developments pointing beyond local significance. This paper examines the historical roots and the current structural characteristics of this spread by looking at the motifs and the choices of collectors, their co-operation with commercial galleries and public museums, as well as the advantages and side-effects of blossoming art patronage. Based on ten years of research, including close to two-hundred interviews with the actors in the art world in Hungary, I argue that private collecting, which had already strongly benefitted from the cultural thaw of the last decades of the Communist regime in the country, has earned over the past quarter-century high social status, the promise of lucrative investment and the liberty of creative self-expression for buyers of modern and, subsequently, contemporary art. The paper aims briefly to place these multiple factors in an international context; further research into art collecting in Eastern Europe will be needed to yield a more complete comparative regional study.
\end{abstract}

Keywords: private collecting, art market, modern and contemporary Hungarian art, art patronage and sponsorship, art museums

Biography: Gábor Ébli earned a PhD in Aesthetics from Eotvos Lorand University in Budapest and one in History from the University of Sydney, Australia. He was a Fulbright Fellow at the New School for Social Research, New York and is currently Associate Professor at the Institute for Theoretical Studies, Moholy-Nagy University of Art and Design, Budapest. He specializes in research on museums and private collections, which combines theoretical approaches to culture with historical inquiry, particularly in relation to modern and contemporary art. His studies on museums, published in Hungarian in two volumes in Budapest $(2005,2011)$ address international issues of museum policy, patterns of representation in permanent and temporary exhibitions, as well as the dilemmas of canonizing the art of the $20^{\text {th }}$ and $21^{\text {st }}$ centuries in these public institutions. A more empirical approach to research, one that focuses on the history and the current development of the art market and of private collecting in Hungary in an East European context, underlies the paper that follows here. 
Ébli, Gábor. "Will Hungarian Private Collectors Turn International? Private Engagement in Contemporary Art in East Central Europe.” AHEA: E-journal of the American Hungarian Educators Association, Volume 5 (2012): http://ahea.net/e-journal/volume-5-2012

The recent spectacular surge in private collecting in Hungary - which began around the fall of Communism and abated, perhaps temporarily, only with the current financial crisis - is best seen in the historical context of the controversial developments of the past twohundred years in that country. By the time much of the cultural network of modern Hungary was set up in the nineteenth century, art collecting had been a narrow aristocratic pastime for a long period, which was soon to spread to wider layers of society. While the National Museum was established by one of the country's wealthiest aristocrats, Count Ferenc Széchényi in 1802, its subsequent major benefactor, Miklós Jankovich came from the landed gentry, a financially and socially less privileged stratum (1832). Although the revolution of 1848 failed, the Compromise with Austria paved the way for political and economic development (1867), so that the new rising middle and upper classes took up the model offered by the upper and lower nobility, and turned to culture for creating an identity, with a resultant prosperity in a Golden Age of art collecting in Hungary from the 1880s until the outbreak of the Great War.

During this quarter-century buyers from ever broader classes came to engage in art, and their taste noticeably shifted towards a modern aesthetic. Among the highest echelons of society, several aristocrats, such as Count Gyula Andrássy, continued with the family tradition of collecting and ventured into the domain of modern art, buying as a matter of course nationally and internationally. At the same time, members of the new, non-hereditary nobility, for instance Baron Ferenc Hatvany, followed suit, promoting modern painting within the country, as well as purchasing excellent works in capitals abroad, mainly from art dealers in Vienna, Paris and, increasingly, Berlin. In a third social stratum, among the self-made entrepreneurs, Marcell Nemes achieved international fame with his collection ranging from El Greco to the Post-Impressionists (on this historical background, see Sármány-Parsons 1993 and 1995).

The disintegration of the Austro-Hungarian Empire brought to a sudden end this Golden Age of culture, with prolonged economic and political demise during most of the inter-war period forcing art collecting into decline. Only a very few buyers of art, such as tobacco-magnate Mór Herzog and industrialist Bertalan Naményi, could afford maintaining the international scope and progressive taste of earlier turn-of-the-century Hungarian collectors, while many of the other holdings amassed prior to World War I were dispersed in the course of 1920s and 1930s, with World War II causing further damage to private collecting. Numerous collectors being of Jewish origin - to name only a few, from among those already mentioned: Hatvany, Nemes, Herzog - the legal and subsequent physical persecution of Jewry in Hungary from the late 1930s onwards severely further decimated collections. During the War, particularly towards its end in 1944/1945, during and directly after the Siege of Budapest, Hungarian, German and Soviet forces looted the remaining collections, including those hidden in depots (Mravik 1998). Finally, the new Communist power attacked collectors on an ideological basis, because of their "bourgeois" habits and the private ownership of the artworks in their hand. The losses in art collections through the war and subsequent spoilage and politically motivated intervention against private collectors amounted in some sections up to an astounding 90\%. Altogether, this series of losses not only in the material holdings of collectors but of the very lives of many can be seen as so extreme 
Ébli, Gábor. "Will Hungarian Private Collectors Turn International? Private Engagement in Contemporary Art in East Central Europe.” AHEA: E-journal of the American Hungarian Educators Association, Volume 5 (2012): http://ahea.net/e-journal/volume-5-2012

that this period (1938-1949) has come to be ironically called by historians as the Sacco di Budapest, referring to the Sacco di Roma half a millennium earlier (Mravik 1988).

During the 1920s and 1930s a number of factors - notably the international isolation of the country, the relatively modest economic means of those interested in art, and a general turning away from the avant-garde, to a less radical aesthetic - called a new strategy of collecting into life. These new amateur collectors, mostly businessmen, physicians and wellto-do intellectuals by profession, such as Béla Radnai, László Cseh-Szombathy and Lajos Fruchter, focused on contemporary Hungarian painting. They befriended each other and the artists, setting up, for instance, the Gresham Circle, a society of painters and patrons with regular meetings in the prestigious Café Gresham. Although most of these collections failed to reach beyond national limits and a refined yet restrained taste, they did propel a new model of art patronage, which continued to live on after World War II (cp. Bodnár 1963, the catalog of the exhibition of private collections from these decades, held in the Hungarian National Gallery). More conservative in their taste than some of their predecessors who had espoused the avant-garde, these new art lovers of the inter-war era represented, nonetheless, far more advanced aesthetic values than official cultural policy, and thus proposed a new model of civil society standing for balanced visual value judgments. As a sign of change in social mobility, also a few women collectors appeared among these new patrons of art, notably physician Bella Kunvári, who had been introduced to the art scene by her sister, an artist of talent, and whose collection eventually was acquired by the art museum of Pécs after World War II.

After 1949, when the Communist regime definitely seized power, art collecting faced new hindrances. Albeit not prohibited, private ownership of artworks became severely restricted in Hungary, and between 1949 and 1956, auctions and other channels of the art market were suspended. Instead of collaborating with collectors, museums assumed functions of authority, overseeing and administering those parts of national cultural wealth that were held in private hands. The one-party-state aimed to shift public taste and the canon of modern art towards values that corresponded to Soviet-type ideology, relegating progressive artists and their not too numerous supporters to the periphery. Nonetheless, after the Revolution of 1956 art collecting was gradually revived, when the regime opted for a more pragmatic course and began to allow for wider liberties in culture. The Gresham model asserted itself again, with mostly physicians and some intellectuals arranging direct contact with artists and each other, setting up circles of friends of the arts, collectors clubs and related schemes, today called civic engagement in art (Molnos 2005). Some of these collectors, for instance Ernö Kolozsváry - a teacher in a grammar school in Gyorr, who when free elections came after the fall of the Iron Curtain, catapulted into the seat of the Mayor of the city - from the 1960s onward professed allegiance to truly avant-garde priorities and acquired excellent works from those artists that the state shunned on ideological grounds (Kolozsváry 1998).

Kolozsváry and his like-minded fellow-collectors, such as Oszkár Köves and Zsolt Pogány, contributed to the gradual revival of the urban, bourgeois habit of civil society to follow their own taste independently of the aesthetic promoted by the political regime. For progressive artists, the moral and financial support offered by collectors often meant the bare means of intellectual and physical survival, as museum purchases, public commissions, awards and prizes favored artists who had jumped on the political bandwagon. Beyond intellectual freedom and symbolic resistance to the authoritarian regime, for the buyers of 
Ébli, Gábor. "Will Hungarian Private Collectors Turn International? Private Engagement in Contemporary Art in East Central Europe.” AHEA: E-journal of the American Hungarian Educators Association, Volume 5 (2012): http://ahea.net/e-journal/volume-5-2012

modern artworks art collecting provided also a form of investment. Prices were low, alternative options for preserving the value of money, or spending it on consumption, were hardly available, whereas an art collection offered aesthetic and, in the long run, potential financial rewards (see, by one of the experts on pre-1989 art collecting, Mravik 1991).

After international contacts had essentially ceased, finally from the mid-1960s onwards, although still within the monopoly of the State Consignment Company (BÁV) and mostly within the national borders, a lively art market did resume. The "goulash Communism" of the 1970s clearly tolerated, in some instances even officially helped, this reanimation of art salons, art journals, exhibitions in the capital as much as in well-funded museums in the countryside, such as in Pécs and Szombathely and, to some extent even abroad. The proper rebirth of the art market and of art collecting from the 1980s onwards cannot be considered an unexpected, new phenomenon, but rather the acceleration of this slow evolution, which had started after the Revolution in 1956. The re-activation of collecting was not the result of the fall of the Iron Curtain but a logical conclusion of the political and economic thaw of the Soviet-type power in Hungary from the 1960s onwards, which allowed for a step-by-step revival of entrepreneurial patterns in art. Naturally, the fall of Communism greatly speeded up these changes, eventually turning art collecting into one of the most dynamic segments of culture in Hungary around the Millennium.

If we consider the recent development over the past quarter-century a rapid but evolutionary process, then it is wise to break it down into shorter periods. From the middle of the 1980s onwards, when ideological control of the old regime had become nominal, art collecting picked up first in early modern art. Under Communism, museums and art historical scholarship had downgraded most proponents of classical modernism, and now new galleries, dealers and collectors attempted to provoke a re-assessment of these painters, sculptors and designers, often helped by younger art historians keen on fresh research. For instance, the Nagybánya Artist Colony, established as the center of plein-air painting in Hungary in 1896, was re-discovered almost a hundred years after its heyday, with the Hungarian National Gallery staging a grand exhibition at the centenary of the colony in 1996. All this reawakening of the demand of collectors and museums alike for classic modern art resulted in the skyrocketing of prices and the alarming rise of fakes. Both effects motivated more and more buyers to shift their interest towards later trends of modern art. Demand from collectors began to focus first on the avant-garde of the early $20^{\text {th }}$ century, then on the art deco of the 1920s and 1930s. Subsequently further interwar waves of modern art were appreciated anew, and slowly interest solidified in post-World War II art, opening the door to contemporary art, which became a strong segment of the art market from around 2000 onwards.

The first decade of the new Millennium brought an apparent growth in the contemporary art market, mainly focused geographically on Budapest (Rozgonyi 2000 gives an empirical overview). Until the current crisis hit in fall 2008, each year had seen more galleries, more buyers, wider media coverage, repeated attempts at establishing contemporary art fairs, various publications on the collections, even Internet-based networks of the new art collectors (Erdősi 2003). This short decade was so intense that it is useful to identify its three major characteristics. First, the notion of contemporary art shifted from covering initially mostly the living classics to including mid-generation and then literally young artists. By 2005, graduation exhibitions at the art academies and other shows of emerging artists had 

East Central Europe.” AHEA: E-journal of the American Hungarian Educators Association, Volume 5 (2012): http://ahea.net/e-journal/volume-5-2012

become packed with gallery managers, collectors and investors. Second, an elite group of no more than two dozen collectors began to visit art fairs abroad and commenced, within the price bracket that most Hungarian buyers are compelled to move because of their financial limits, to acquire works by international artists in an attempt to position their collection beyond national borders. Third, taste markedly shifted towards conceptual art. Discovering the riches of political and philosophical connotations in the classic conceptualism of four decades ago as much as in recent neo-conceptual positions, and feeling that conceptual art in many cases better expressed the Zeitgeist than popular painting, a growing number of buyers came to covet these progressive works. This threefold turn towards younger, international and more experimental art often overlaps, its elements reinforcing each other. Collectors going international realize faster how narrow the traditional Hungarian taste for painting and for securely positioned senior artists is, and vice versa, those with a liking for conceptual works and younger artists are more likely to want to break free of national constrains, in order to mix their Hungarian holdings with universal art (for an illustrative case, see Mayer 2006a).

Having recapitulated the historical development of the past two hundred years, let us now turn to the details of the recent trends, primarily to the motifs for collecting contemporary art today. Historically, under Communism, asserting civic identity as a form of non-violent resistance to brainwashing by the Party was one of the key drives for acquiring progressive works. Although this factor appears irrelevant today, we can actually still find it now, only in a new robe. Instead of ideological monotony, today overpowering capitalism and its material values rule everyday life, against which some collectors look for a safe intellectual haven in the realm of art. In this sense, for some people, art collecting functions as a sort of escapism, with buyers constructing a second, alternative reality for themselves by acquiring works that they feel offer a different, usually more traditional system of values, and serve as a shield against profit- and media-driven everyday life. As a second motif, we already mentioned investment, and this aspect has indeed strengthened significantly. Beginning in the late 1980s new groups in society began to acquire great wealth within a short period of time, and although these groups have often changed over the past three decades, most of them have considered art a possible investment in their portfolio. Even in recent years, as the real estate and the stock exchange boom had stopped, some people have turned to contemporary art for investment. Most of these buyers prefer direct contact with artists, making bulk purchases at heavy discounts in the studio. In order to diversify their selections, they acquire aesthetically different groups of works, which hardly make up a coherent collection, yet appear to guarantee a balanced future (a case in point being Körmendi 2001). Some of the works will prove a failure, while others will earn high profit, the point for the owner being that the holding shall be successful overall. While many of these collectors treat acquiring art as other investors treat stock purchase, attempting to acquire what is called a balanced portfolio, by going through this process of learning, some of these first-generation art investors eventually grow into true art lovers, proper collectors.

Other motifs besides shrewd financial investing for collecting are no less important. Just as plein-air painting and other early modern art was a field of new insights two or three decades ago, from the late 1990s contemporary art became a terrain for visual exploration. The oeuvre of dozens of talented artists of the last third of the twentieth century, unable to make a career under Communism due to political control and the lack of an efficient gallery 
Ébli, Gábor. "Will Hungarian Private Collectors Turn International? Private Engagement in Contemporary Art in East Central Europe.” AHEA: E-journal of the American Hungarian Educators Association, Volume 5 (2012): http://ahea.net/e-journal/volume-5-2012

system, came to light step by step, mostly by the efforts of dealers, gallerists and researchminded collectors. Collectors willing to take risks also ventured into buying sculpture, plastic works and objects, most of which have traditionally been less preferred by the Hungarian art market. The so-called new media art, video, inter-media and other experimental forms now likewise have their own collectors, who appreciate this kind of art, as well as the feeling of being among the first to do so in Hungary. This feeling of a pioneer spirit is one of the mental rewards of collecting, and it also promises material gains, provided new discoveries can be turned into a trend, which prompted some collectors even to publish their own guide to becoming a dynamic actor of the art market (see, for instance, Rechnitzer 2002).

Next to this fever of discovery, the intent of visual (self-)education ranks surprisingly high among the motifs of collectors in Hungary. Buyers of art tend to begin reading about what they acquire, and set about putting together a library of catalogues and art books. Whilst this may only be natural for a Western audience, let us not forget that public visual education in Hungary and elsewhere in our region was for four decades politically controlled, and, albeit ideologically liberated today, it is still mediocre. Although Communism is gone, the school system has nevertheless barely incorporated attention to fine art, let alone its contemporary trends. For many well-educated people, going to exhibitions, leafing through catalogues, and having modern and contemporary art albums on the shelf at home, cannot be seen as selfevident, but rather must be learned to be understood as part of ordinary life. Conditioning their eye to the values of contemporary art is, in this sense, a challenge, a program for many collectors. They educate themselves, their children, often their colleagues, friends, even business partners - most easily by taking works from their private collection into office spaces and by hosting art salons by invitation only, such as those run by Katalin Spengler and Gábor Pados, two of the most influential collectors of contemporary art.

Having contemporary artworks around became noticeably fashionable from around 2000 onwards, as it emanates a certain feel for intellectual finesse and up-to-date social trends. Art collecting became a status symbol, standing for the (alleged) intellectual and financial ammunition of the person or company showing it (cp. the interview-based album with figures of high society, Gulyás and Szeleczky 2008). For example, while today’s businessmen grew up often among poor-quality posters, some of them are now getting used to living with art, and elevating the rank of their office by the works they hang there. While most art critics look down on the effects of art testifying to social status, dropping whimsical hints in their essays about this "new habit of the nouveaux-riche", their irony misses a useful impact of this new fashion. Trends always call for followers, and attention to art spreads very much by way of such examples, models, and the behavior of reference groups. If we yearn for wider moral and material support for contemporary art, then its status not only in the private sphere but also in public spaces of business and civic life needs encouraging.

Collecting can also be a medicine for the thirst for new human relations, with quite a few actors of the scene trying to collect friends rather than art. The ambition of buyers of art to frequent artists' circles is part of the social aspect of art and art collecting, which has now for decades been on the rise in Hungary, perhaps as a reaction to the more restricted civil society under Communism. Today lawyers and brokers, media figures and top managers seem to share a penchant for getting to know the person whose works they collect, and for establishing a contact that they often deem "friendly" with these artists. In my experience the 
Ébli, Gábor. "Will Hungarian Private Collectors Turn International? Private Engagement in Contemporary Art in East Central Europe.” AHEA: E-journal of the American Hungarian Educators Association, Volume 5 (2012): http://ahea.net/e-journal/volume-5-2012

artists share this “friendship” less enthusiastically, yet play the role happily for obvious reasons. At any rate, collecting is a means of communication for large segments of the buyers with a creative world different from their rational business environment. They build up a network of artist acquaintances parallel to their private and business relations, and often spend increasing amounts of time in this new niche of their life (cp. Balogh 2006). Socializing of this kind is still dominated by men, with only a few women collectors on the scene, whose purchases cannot be labeled characteristically female. The only domain with a marked female touch is the collecting of design items, such as contemporary jewelry. At the same time, curatorial work and art management seem to be increasingly influenced by women. More and more projects, exhibitions and campaigns are thought out by women, and students in arts management courses show an overwhelming female majority. As numerous female artists make a career in the Hungarian art world, by perhaps somewhat simplifying the situation one could sum up the question of the gender ratio by saying that still mostly male collectors pay for the art that is increasingly created by women artists and is also to a growing extent exhibited and marketed by female curators, art historians and art managers.

Collecting art can also be a goal in itself, given that the adrenaline boost of locating the work desired, striking a bargain with the artist or with the gallery, and then taking the trophy home, must not be underestimated. Hunting, rivalry, championship over others - all this is part of the psychological record of collectors, with many people who come to the world of contemporary art keen to show the same strengths that they rely on in business, politics or the media (cp. collector profiles by London 2008). The fact, quite characteristic of the Hungarian scene, that many collectors like buying and selling, or swapping, works again and again, signals that for them the very process of collecting, with its steps of realizing a profit, getting into contact with other actors of the market and measuring their positions against each other, is essential. Many collectors watch with envy what others have acquired and regard art collecting as a competitive "game people play".

While the assessment of the various motifs in the past paragraphs may seem too critical, this list is not to deny that collectors often love the works they possess, and feel that these pieces of art express their hidden, innermost self that they are otherwise unable to vent openly in family or business. Quite a few buyers are sensitive to the artists' needs, try to help them in dire circumstances, and set up small private schemes of art patronage to support artists and start-up institutions (cp. Berecz 2001). In most cases, however, they expect - and receive - something in return. Truly selfless assistance is rare, and perhaps it is not even reasonable to expect help without interest in the artist-collector relationship. Realistically seen, in most cases when exhibitions, catalogs or other services for an artist are sponsored by private individuals or companies, we can suppose that the artist returns the favor with handing over artwork, which reveals the act of patronage as sheer purchasing of art, only communicated in a euphemistic and media-conscious way. In short, patronage can be cited among the motifs for collecting art, yet in a number of cases the label "patronage" serves but the nice media coverage, and actually behind the scene hard bargaining takes place.

Finally, a surprising element rounds up our list of motifs of art collecting. Although rarely selfless, collectors have, nonetheless, a complex sense of responsibility in a broad sense for society at large. Many - especially those engaging internationally - feel that by acquiring, cataloguing and publicly showing high-quality contemporary works, they contribute to the 
Ébli, Gábor. "Will Hungarian Private Collectors Turn International? Private Engagement in Contemporary Art in East Central Europe.” AHEA: E-journal of the American Hungarian Educators Association, Volume 5 (2012): http://ahea.net/e-journal/volume-5-2012

intellectual wealth of the nation and to the image of the country abroad. In this sense, art collecting, especially the espousal of experimental works and the presentation of national and foreign artists together, can be interpreted as a mission, a contribution to the public good. The limited international reach of Hungarian art explains why I have not given more names in the paragraphs so far. Even the big fish in our small pond mean little to foreign readers, while those Hungarian artists who do have some recognition abroad - mostly neo-conceptual midcareer figures, such as Róza El-Hassan, Attila Csörgő, or the Kis Varsó duo - are underrepresented in Hungarian collections. In contrast, sought-after local artists, such as Imre Bukta and László feLugossy [sic], have limited reference abroad. A large number of art collectors are aware of this gap between the national scene and the international art world, and attempt to promote the integration of Hungarian art globally in three characteristically different ways. First, a few businessmen collectors - such as Zsolt Somlói, László Gerő and Béla Horváth - are based in Hungary but travel regularly to international events of the art world, becoming more and more successful in establishing solid contacts to galleries, artists, curators abroad, which is a pivotal contribution to positioning the Hungarian art scene as an active partner in various schemes of international collaboration (cp. Mayer 2006b). Second, some of the art collectors live abroad because of their professional career having turned international after the fall of the Iron Curtain, among them Gábor Hunya in Vienna, András Szöllősi-Nagy in Paris, József Böhm in Dresden, trying to position their Hungarian collections in the context of the foreign art scene they live in (from among their catalogs, see Arnaud 2002 and Kürti 2009). Third, a number of foreigners, neither of Hungarian origin, nor usually living for long in Hungary, but some of them having spent considerable time here such as former US Ambassador to Hungary Nancy G. Brinker - have built up quite valuable collections of Hungarian art, with some of them, for instance US businessman H. Kirk Brown, playing a significant role in publishing catalogs, organizing exhibitions, and thereby functioning as a reference for other potential foreign buyers to believe in Hungarian art (Forgács 2007). In sum, collecting and showing Hungarian art in an international context can be a powerful tool for representing the country's cultural wealth.

Having looked at the historical background and the motivation of collecting, let us examine the structure of collections. The first specificity to note is the link between modern and contemporary art. As we have seen, quite a few collectors had arrived at contemporary art via modern art. Thus a number of collections offer a fairly complete view of twentieth century Hungarian art, which embeds today's art in an evolutionary context and strengthens the image of today's artists by suggesting that, with time, their works shall enjoy the same canonization that their precursors had gone through. This combination of buying first, in the 1980s and 1990s, modern art and switching to contemporary art around the Millennium was a one-time chance for collectors who could afford buying high-quality works right from the current, large-scale rebirth of the art market from the late 1980s onwards, while for those who began to collect from the late 1990s onwards, this option was financially no longer feasible as classic modernism had become too expensive. Therefore in the younger generation of collectors we mostly find art holdings made up of exclusively contemporary works, and these works are hardly placed in an evolutionary line.

In terms of the medium of art favored most, painting dominates selections, with other forms, such as graphics and sculpture, being less popular, although their position has been 

East Central Europe.” AHEA: E-journal of the American Hungarian Educators Association, Volume 5 (2012): http://ahea.net/e-journal/volume-5-2012

improving over the last decade as the price rise of paintings has made buyers to include more and more works different from the oil-on-canvas fashion. To date only a minority of collectors are interested in the new technical media - for instance photography, video, multimedia installation, sound and light based object art, as well as other ephemeral, site-specific and mixed media - yet the past decade has witnessed a steady spread of such works. A large number of artists and galleries have given up showing paintings and have gone instead into producing and exhibiting more experimental media works, spurring the buyers to make new choices. The growing international exposure of the Hungarian art world - a result of accession to the EU and globalization at large, as much as of conscious efforts by leading Hungarian art managers - also contributes to the spread of progressive media art, as many more players of the local art scene now have a chance to gain regular first-hand comparison with experimental international trends than was the case in the 1990s (cp., by a collector herself, Spengler 2003). As a last reason for the growing acceptance of non-traditional media by art collectors, the broadening exchange of information between museums and collectors in Hungary needs highlighting. Traditionally, the relationship of art historians and private buyers having been quite reserved and based often on prejudice, rather than live contacts, the canon followed by many collectors was much more conservative than that suggested by museums. Now that younger curators and collectors are more willing to get to know each other and openly discuss relevant issues, the model role of museums becomes more important. Many collectors have opted to follow the museums' preference for experimental new media.

After museums, it is the galleries that exert a growing influence on the choices of collectors, the hard-earned result of a process of twenty years. Although commercial galleries began sprouting immediately after the fall of the Wall, during the first years many of them failed to secure regular purchases from buyers. As the gallery system was new, art collectors had first to gain trust of the galleries and learn why they are an indispensable element in the value chain of contemporary art (Honyec 1997 is an interview-based study of the first years of galleries in Hungary after the transition). Gradually, as the galleries began publishing catalogs for their artists, represented them with increasing professionalism at art fairs abroad, secured regular media coverage for them, and relived them of the practical tasks of art management, the artists came to appreciate the assistance of galleries, with buyers also coming to acknowledge the merits of this collaboration and showing more willingness to buy from the galleries rather than directly - and often at prices significantly below the market level - in artist studios. First, in the 1990s, many buyers enjoyed a financial advantage over the struggling young galleries, and therefore could call the shots, yet by now a balanced relationship has set in, not last due to the know-how that galleries had accumulated and the international expertise they can capitalize on. For an increasing number of buyers, the galleries have become a reliable source of orientation in the complex mechanisms of the art market, especially in the international context, with which Hungarian buyers are still largely unfamiliar with, and for this advice the buyers are ready to support the galleries by making their purchases there, at higher prices than in the ateliers. As a result, some collections betray immediately, at first look the decisive impact of the gallery standing behind them, while in other cases the collector retains the right of selection stronger, by buying from a mix of galleries, yet accepting the dictate of the market that purchases have to be carried out increasingly by way of a gallery. The co-operation of galleries and collectors motivates more 
Ébli, Gábor. "Will Hungarian Private Collectors Turn International? Private Engagement in Contemporary Art in East Central Europe.” AHEA: E-journal of the American Hungarian Educators Association, Volume 5 (2012): http://ahea.net/e-journal/volume-5-2012

and more artists to ally with galleries, which, in turn, forces a growing circle of collectors to frequent the galleries and art dealers. The system of collecting is thus becoming more and more institutionalized in Hungary, with the once rather spontaneous acquisition of works giving way to a well-structured art market (cp. the Introduction to Készman 2005). Although the current slump has overwritten the situation, as financial pressure makes many artists and buyers negotiate directly with each other, letting down the galleries, in the long run the role of galleries is unlikely to weaken. The history of the art market in Hungary during the past quarter-century since the fall of the Iron Curtain can, from this point of view, be subsumed under the broad label of the institutional channels of the art trade - first the auctions, subsequently the galleries - replacing the direct seller-buyer relationships.

In contrast to museums and galleries, the art fairs in the country - held mainly in Budapest and occasionally in nearby Szentendre - exert only modest influence on what kind of art people buy. Hungary has failed so far to establish a contemporary art fair with regional relevance, and the national art fairs, held each year, with their title, location and management often changing, attract within Hungary only the same public that visits the galleries over the year anyhow, and offer them nearly the same artworks that they could find at any other time (Kenessei 2003). The sales made at these fairs could just as well take place in the galleries, thus the fair as an ideally concentrated, trend-setting event has actually no clearly identifiable impact on collecting. Across the border, international fairs do have a rapidly growing effect on the Hungarian scene, and about a dozen leading Hungarian galleries regularly apply to participate in these prestigious events, as much as the leading Hungarian collectors attempt to shell out the money for acquiring international works at these fairs. Participation in the international events of the art world leads to a certain globalization of the gallery and collecting scene in the country, as the flagships follow more and more the international trends, and these effects trickle down to the smaller, local players.

Due to the large sums of money involved and the trend-setting character of the art market, private collecting enjoys broad publicity in Hungary. The willingness of collectors to show their works, and talk about their passion, is considerable, and in my experience bigger than elsewhere in the Western world, with some even publishing their collection on the Internet (cp. www.nemethcollection.hu and www.nagymiklos.hu/collection). Although many increasingly fear the "three evils" of publicity - the tax office, burglary and public envy there is still regular coverage of art collecting by a few specialized art writers, just as exhibitions of private collections expand. Particularly Budapest, with its surprisingly dense network of exhibition spaces, amounting to at least one hundred locations, from well-run commercial galleries to off-spaces for non-conformist art, offers insights into private holdings literally at any time of the year. Several galleries, such the non-profit Vízivárosi Galéria and the for-profit Godot Galéria, have introduced series showing private collections once or twice a year. Collectors are aware of the rise of the value of their works due to these exhibitions, and they also learn a lot from seeing their choices in a more critical, distanced manner in the neutral space of a gallery. Their position vis-a-vis the galleries and the artists likewise improves with these exhibitions, as these exhibitions of individual collections become an agent of publicity for the artists and the galleries, too. At the same time, with few exceptions, such as the Kassák Museum, larger public institutions rarely show private collections (from among the catalogs of the Kassák Múzeum, see Csaplár 1989). In 2008, the Hungarian 
Ébli, Gábor. "Will Hungarian Private Collectors Turn International? Private Engagement in Contemporary Art in East Central Europe.” AHEA: E-journal of the American Hungarian Educators Association, Volume 5 (2012): http://ahea.net/e-journal/volume-5-2012

National Gallery broke the ice with a successful show of the Irokéz Collection, but this has so far remained just the exception to the rule (cp. the book-size catalog, Kozma 2008). For the leading contemporary institution of the Hungarian scene, the Ludwig Museum - Museum of Contemporary Art, established 1996, showing a private collection is entirely out of question as this museum draws a clear line between public mission and private choices. In 2008, another key public institution, the Kunsthalle took a forward-looking initiative, by staging two grand, albeit short, exhibitions with its prominent, vast halls given over to a private collection each (Somlyódy 2009). Altogether the two exhibitions presented around twenty collections, yet the shows were reviewed unfavorably, and the series has not continued.

A few collectors have set about establishing their own museums. In Tapolca, two hours' drive from Budapest, Ákos Vörösváry renovated a spectacular old mill, turning it into an exhibition centre for his vast collection, with exhibitions running there for nearly two decades now (Dékei 2008). In nearby Veszprém, László Vass allied with the municipality, and EU-funded re-construction of three downtown villas allowed for his museum to open in an attractive setting, with exhibitions living up to international standards (Sík 1997). In Debrecen, a major university city in Eastern Hungary, the vast new exhibition centre Modem, built and run by the municipality, has a long-term deposit contract with lawyer Péter Antal to show changing chapters of his increasingly international collection (cp. the numerous catalogs, e. g., edited by the then Director of Modem, Gulyás 2006). In 2000, when MEO, opened in Budapest, this private museum for contemporary art was one of the most promising developments. An old factory had been spectacularly revamped, talented curators began to stage progressive exhibitions, and a growing private collection seemed to be standing behind, yet soon various economic, legal and ethical problems led to the failure of the project (Sütö 2003). Kogart, another private foundation in downtown Budapest, established in 2004, is known for its visitor-friendly exhibitions, yet the contemporary vocation of its program and collection is compromised by conservative and populist choices (see the first of the catalogs of their contemporary collection, Fertőszögi 2008). The unstable quality of exhibitions in other private initiatives, e.g. APA and VAM, testify to a central dilemma of these institutions: if the aesthetic mission and the collection are progressive, then financing them will almost inevitably prove very difficult, or if the institution aims to be financially self-sustainable then it will find it very challenging to meet professional standards (Csóka 2003). In Balatonfüred, Töreki and Várgesztes, a private artist colony each provides the framework for creatively collaborating with artists, and building up a collection. Although various further examples could be mentioned, the future of these has become rather uncertain in the current prolonged crisis. Nonetheless, among the over one hundred private collections of contemporary art in Hungary there are several ones that keep seeking further options for working as a publicly accessible private institution.

Among private institutions, corporate collections played an ascending role for over a decade immediately after the fall of the Iron Curtain. Although nowhere close to the intensity of business involvement in contemporary art as we know it globally, compared to the economic limits of the country, from the early 1990s onwards, companies in Hungary duly commenced to sponsor exhibitions, build up collections, decorate their offices with artworks, fund art prizes, and seek image-polishing through other forms of co-operating with art institutions (Arnold 2004 provides case studies). Among these, the contemporary collection of 
Ébli, Gábor. "Will Hungarian Private Collectors Turn International? Private Engagement in Contemporary Art in East Central Europe.” AHEA: E-journal of the American Hungarian Educators Association, Volume 5 (2012): http://ahea.net/e-journal/volume-5-2012

Raiffeisen Bank has remained to date one of the successful projects, whereas in the category of company-funded yearly art prizes the Strabag Award dominated the scene until the firm had changed its priorities a few years ago (Hajdu 2002). The current crisis having slashed company budgets for cultural sponsoring across the board, it is now an open question if and how these co-operations between business and contemporary art will resume.

Another type of institutional collections rests on non-profit objectives. As elsewhere in the world, artists themselves are avid collectors in Hungary. In part, they collect art individually, but some of them team up. Many of the individual collections, such as that of László Fehér, Tamás Konok, István Haraszty and Ákos Matzon, have become known through numerous exhibitions, and there are dozens more. Most artists build their holdings by way of exchange, and this opens the way to international works, too, that would otherwise be financially difficult to obtain. A few artists, for instance Imre Bak, became known for that as early as in the 1970s, with museums borrowing foreign works from them; and artist collectors are still at the forefront of international collecting in the country. Among those who have joined forces in order to promote their own oeuvre and their collections widely, the most successful case is the Open Structures Art Society, directed by Dóra Maurer, a pivotal figure of the neo-avant-garde of the 1970s. Likewise devoted to geometric art, the Mobile MADI Museum is another art collection managed by a group of artists. From the 1990s onwards, numerous other foundations, educational institutions and other civil bodies learned to identify art collecting as an efficient tool for strengthening and publicly expressing their identity. Also a number of former émigrés, for instance Mária Marghescu and Miklós Bay, returned to Hungary and repatriated the art collections they had assembled abroad, partly enriching by donations various foundations of modern and contemporary art, such as the Véghelyi Foundation established by the Museum of Fine Arts (Geskó 1999). Many foreigners spending a few years in Hungary for reasons of employment or family likewise took up buying Hungarian art systematically and their collections play a strong model role through exhibitions and catalogs, as well as through the institutional forms they set up, the best-known example being the US-based foundation of former US Ambassador to Budapest Nicholas Salgo (Salgo 1991). However different the legal and financial background of these foundations has remained, they radiate the conviction that modern and contemporary artworks from Hungary are worth collecting and publicly showing.

Overall, a key finding of this research I carried out between 2000 and 2010 - by interviewing collectors or their heirs and family, as well as by curating exhibitions of collections and writing catalogs for these shows - is that contemporary art grew into a rather popular form of the passion and the rational calculation of the most varied individual and institutional groups of collectors in Hungary (in more detail, see Ébli 2006 and Ébli 2008). True, these collections betray extreme differences in the quality and type of works acquired, with the national art market having remained far from homogenous and transparent. It is exactly the discrepancy of a lively scene, of uneven and contradictory structure, for contemporary collecting in the country that describes the situation of the 2000s in Hungary best. The slump since 2008 has severely shaken the art market, with many collections being up for sale - were there anyone to buy them. Only time will tell if economic recovery refuels art collecting to the level of the peak years around 2005-2007 in the country, either with the same actors and structures or with new settings. 
Ébli, Gábor. "Will Hungarian Private Collectors Turn International? Private Engagement in Contemporary Art in East Central Europe.” AHEA: E-journal of the American Hungarian Educators Association, Volume 5 (2012):

http://ahea.net/e-journal/volume-5-2012

To interpret the results of the past quarter-century realistically, it is useful to place the Hungarian case in a brief comparison with other ex-Communist countries. Collecting systematically the art of Eastern Europe with a broad regional outlook has remained rare both in Hungary and elsewhere in the former Soviet bloc (for an overview of the reasons, by a collector, see Weichardt 1991). Although the artistic positions of these neighboring countries would mutually strengthen each other - as the permanent exhibitions of several East European museums, including the Ludwig Museum in Budapest, testify - private collectors put no trust in piecing together regional groups of artworks, as they are afraid that the East European names in and by themselves would fail to attract proper international attention. By contrast, collecting contemporary is a strategy for the elite of these countries to catch up with the global powers in art, with the task of the collections being to prove to the wide world that the artists and collectors of each nation here in East Europe belong to the global art world. Instead of collecting the art of one another, the art fanatics of each East European country strive to acquire key works of their national contemporary art scene and promote these into the 'Western', or international canon of art. This attitude can be regarded as a therapy of inferiority complexes, where the collectors in each East European nation pursue the same strategy of trying to elevate their own national art to the international level, skipping the regional level, without noting that every other nation in the region struggles the same way and that doing this jointly would actually earn much more attention in the world.

Seen on the national level, the rise of art collecting in Hungary from the late 1980s to the late 2000s was one of the most successful developments of culture in post-Communist Eastern Europe. No other capital in the region boasts as many galleries as there are in Budapest, and the range and the publicity of Hungarian private collectors of contemporary art being second to none in the region, suggests that goulash Communism had fermented various proto-entrepreneurial skills in the world of culture in Hungary that prepared the art market for dynamic development after the fall of the Wall, lasting about two decades. By the late 2000s, this growth had reached its national limits, with some Hungarian initiatives pointing towards international opening, yet overall, the art market of Poland, Romania and some other countries showing far more dynamism over the past 4-5 years than that of Hungary. Only the coming years will show if the Hungarian galleries, collectors, artists and curators will find new ways to overcome the effects of the economic crisis and to integrate the art scene of the country internationally. 


\section{Works Cited}

Arnaud, Jean-Pierre. ed. 2002. Artistes hongrois en France 1920-2000 autours de la collection Szöllösi-Nagy-Nemes. [Hungarian Artists in France, 1920-2000, Around the Szöllösi-Nagy-Nemes Collection] Angers: Présence de l’Art Contemporain.

Arnold, István. ed. 2004. Jelentés a magyar kultúra magántámogatásáról 2004. [Report on the Private Support for Hungarian Culture, 2004] Budapest: Summa Artium.

Balogh, Péter. ed. 2006. Amadeus Album (1999-2006) - Fundamenta Gyüjtemény. [Amadeus Album (1999-2006) - Fundamenta Collection] Budapest: Amadeus Alapítvány.

Berecz, Ágnes. 2001. Contemporary Hungarian Painters in Association with the Shashoua Collection. Selected and edited by Eva Skelley. London: Shashoua Press.

Bodnár, Éva. ed. 1963. XX. századi müvek budapesti mügyüjteményekböl. [20th c. Works from Private Collections in Budapest] Budapest: Magyar Nemzeti Galéria.

Csaplár, Ferenc. ed. 1989. Kassák. Festmények és grafikák hazai magángyüjteményekböl. [Kassák. Paintings and Graphics from Hungarian Private Collections] Budapest: Kassák Múzeum.

Csóka, Veronika. 2003. ”A.P.A. - Ateliers Pro Arts”, in Zsófia Németh, ed., Public Spaces of Modern Architecture in Budapest. Volume II: Artist Studios and Exhibition Places. Budapest: Ernst Museum, 65-69.

Dékei, Krisztina. ed. 2008. A mügyüjtés dicsérete. 15 éves a Látványtár. [Art Collecting Acclaimed. 15 Years of the Látványtár Collection] Budapest: Első Magyar Látványtár Alapítvány.

Ébli, Gábor. 2006. Magyar mügyüjtemények 1945-2005. [Hungarian Private Collections, 1945-2005] Budapest: Enciklopédia.

Ébli, Gábor. 2008. Mügyüjtés, múzeum, mecenatúra. Esettanulmányok a jelenkori magyar gyüjtéstörténetböl. [Art Collecting, Museums and Art Patronage. Case Studies on the Recent History of Collecting in Hungary] Budapest: Corvina.

Erdősi, Anikó. 2003, “The Appearance of Private Contemporary Art Galleries in Budapest in the 1990s”, in Zsófia Németh, ed., Public Spaces of Modern Architecture in Budapest. Volume II: Artist Studios and Exhibition Places. Budapest: Ernst Museum, 248-259.

Fertőszögi, Péter. ed. 2008. Kogart Kortárs Müvészeti Gyüjtemény 2008. [Kogart Contemporary Art Collection] Budapest: Kogart.

Forgács, Éva. 2007. Hungarian Artists: An Exhibition of Passion, Interludes and Progress. The Collection of Former US Ambassador Nancy G. Brinker. Tequesta, Fl.: Lighthouse Center for the Arts, $2^{\text {nd }}$ ed.

Geskó, Judit. ed. 1999. Pictures of a private collection. Works of Miró, Tápies, Chillida, Alechinsky and their contemporaries in the Marghescu collection. Budapest: Museum of Fine Arts.

Gulyás, Gábor. ed. 2006. Kilencvenkilenc év. Antal-Lusztig Gyüjtemény I., [Ninety-Nine Years. Antal-Lusztig Collection, I.] Debrecen, Modem Művészeti Központ.

Gulyás, Judit and Ildikó Szeleczky. 2008. Gyüjtőszenvedély. [The Passion of Collecting] Budapest: Geobook. 

East Central Europe.” AHEA: E-journal of the American Hungarian Educators Association, Volume 5 (2012): http://ahea.net/e-journal/volume-5-2012

Hajdu, István. ed. 2002. Magyar képzömüvészet az ezredfordulón. A Raiffeisen Gyüjtemény [Hungarian Art at the Millennium. The Raiffeisen Collection] Budapest: Athenaeum.

Honyec, Ágnes. 1997. A mükereskedelem aktuális helyzete Magyarországon. [The Current State of the Art Trade in Hungary] MA thesis, Budapest: Eotvos Lorand University, Department of Art History.

Kenessei, András. 2003. 'Modern magyar mükereskedelem' [Modern Art Trade in Hungary], in Krisztina Lendvai, ed. Galéria 2003. A magyar mükereskedelem évkönyve. [Galleries 2003. Yearbook of the Hungarian Art Trade 2003] Budapest: Win kommunikációs kft, $1-40$.

Készman, József. 2005. Magyarországi kortársmüvészet az ezredfordulón. [Contemporary Hungarian Art at the Millennium] Budapest: BUMBUM.

Kolozsváry, Marianna. ed. 1998. Modern magyar müvészet a Kolozsváry-gyüjteményben. [Modern Hungarian Art in the Kolozsváry Collection] Budapest: Kolozsváry Gyüjtemény Alapítvány és Mücsarnok.

Körmendi, Anna. ed. 2001. Körmendi-Csák Gyüjtemény. Kortárs magyar müvészet. [Körmendi-Csák Collection. Contemporary Hungarian Art] Budapest: Körmendi Galéria.

Kozma, Zsolt. ed. 2008. Irokéz Collection. Budapest: Golyós Toll kft.

Kürti, Emese. ed. 2009. Bucharest Budapest Bridge. Contemporary Romanian and Hungarian Art. The Gábor Hunya Collection. Budapest, Vince.

London, Katalin. 2008. Túlélésre ítélt tárgyak. [Objects Doomed to Survive] Budapest: Athenaeum.

Mayer, Antje. 2006a. “Der Szene verbunden. Das junge Budapester Sammlerehepaar Katalin Spengler und Zsolt Somlói“ [Committed to the Scene. The Young Hungarian Collector Couple, Katalin Spengler and Zsolt Somlói], Spike 9: 3, 88-91.

Mayer, Antje. 2006b. "Selbstbewusst: Zsolt Somlói und Katalin Spengler gehören in Ungarn zu den Topsammlern“ [Confident: Zsolt Somlói and Katalin Spengler Belong to the Top Collectors in Hungary], Kunstzeitung 8: 8.

Molnos, Péter. 2005. ”'I’ve enjoyed every minute of it“. The Kolozsváry Collection“, Art Magazin special edition in English, 18-21.

Mravik László. 1998. “Hungary’s Pillaged Art Heritage”, 2 parts, Hungarian Quarterly 149: 96-106 and 150: 53-79.

Mravik, László. 1991. 'A hatvanas évek magyar mügyüjtése' [Hungarian Art Collecting in the Sixties], in Ildikó Nagy, ed., Hatvanas évek. Új törekvések a magyar képzömüvészetben. [Sixties. New Tendencies in Hungarian Fine Art] Budapest: Magyar Nemzeti Galéria, 33-40.

Mravik, László. ed. 1988. 'Sacco di Budapest’ and Depredation of Hungary 1938-1949. Budapest: Magyar Nemzeti Galéria.

Rechnitzer János. 2002. (Mü)gyüjteni, de hogyan? [Collect Art, But How?] Győr: Régió Art.

Rozgonyi, Krisztina. 2000. ”A magyar mükereskedelem felvirágzása a 90-es évek második felében" [Blossoming of the Hungarian Art Trade in the Second Half of the Nineties], in Erzsébet Marton, ed., Jelentés. A Kulturális Örökség Igazgatóságának Évkönyve 2000. 

East Central Europe.” AHEA: E-journal of the American Hungarian Educators Association, Volume 5 (2012): http://ahea.net/e-journal/volume-5-2012

[Report. Yearbook of the Directorate of Cultural Heritage, 2000] Budapest: Kulturális Örökség Igazgatósága, 40-45.

Salgo, Nicholas. ed. 1991. Two Centuries of Hungarian Painters 1820-1970: A Catalogue of the Nicholas M. Salgo Collection. Washington, D. C.: American University Press.

Sármány-Parsons, Ilona. 1995. "Jewish Art Patronage in Budapest at the Turn of the Century”, in Central European University History Department Yearbook 1994-1995. Budapest: Central European University, 113-132.

Sármány-Parsons, Ilona. 1993. "Notes on Patronage of Modernism in the Fine Arts in Vienna and Budapest at the Turn of the Century", in Central European University History Department Yearbook. Budapest: Central European University, 145-154.

Sík Csaba. 1997. A Vass-gyüjtemény. [The Vass Collection] Budapest: Art V Premier

Somlyódy, Nóra. 2009. ”A nemzetközi színtér nem bajnokság. Tizenegy kortárs magángyüjtemény a Mücsarnokban”, [The International Scene is No Championship. Eleven Contemporary Private Collections in Mücsarnok] Müértö 12:1, 8-9.

Spengler, Katalin. 2003. "Das Sammeln zeitgenössischer Kunst in Ungarn“ [Collecting Contemporary Art in Hungary], in KunstKöln 2003 Katalog. Köln: Koelnmesse, 41-42.

Sütő, András Balázs, 2003. "MEO: Contemporary Art Collection”, in Zsófia Németh, ed., Public Spaces of Modern Architecture in Budapest. Volume II: Artist Studios and Exhibition Places. Budapest: Ernst Museum, 175-180.

Weichardt, Jürgen. 1991. "Ostmitteleuropäische zeitgenössische Kunst: Erfahrungen eines Sammlers“ [Contemporary Art from East Central Europe: Experiences of a Collector], in Thomas Strauss, ed., Westkunst - Ostkunst. Absonderung oder Integration? Materialien zu einer Standortbestimmung. München: Scaneg Verlag, 213-220. 